gen content (contained only in a transition polymer) in the product obained by hydrolysis of the polymer. This result shows that the fraction of each structure can be quantitatively determined by chemical analysis. Further, the optical density of the IR spectrum of a secondary amide group in a transition polymer shows a good correlation with the fraction of transition polymer determined by chemical analysis. Therefore, the IR spectrum can be used as a simple method for determining fraction of transition polymer.

By experiments on the fractionation of the polymer by water, and from melting-point measurements, it is found that PAAm obtained by a conventional anionic catalyst contains both transition and vinyl structures in one polymer chain.

第 2 報 金属 sec-ブトキシド触媒を用いた場合の重合条件と

ポリマー構造との関係

(1965 年 11 月 1 日受理)

中山博 之*・東 村敏 延* ・岡 村誠三*

\begin{abstract}
要旨 第 1 報》に述べたポリマー組成の定量法を用いて, sec-BuONa 触媒とした場合の重合条件 による転位重合の割合の変化を検郡した。その結果, 高重合萃, 低モノマー灌度および高触媒濃度で転位重合 物の割合の大きいポリマーの得られることが明らかとなった。また，トルエン，クロルベンゼン，ニトロベン ゼンのような芳香族系溶媒では，その誘電率が高くなると転位重合の割合は減少し，ジオキサン，ピリジン， DMF のような塩基性溶媒では，その誘電率が高くなると転位重合の割合は增大した。一方， (sec-BuO $)_{2} \mathrm{Ca}$ を触媒に用いると芳香族系溶媒は生成ポリマーの構造に対して sec-BuONa と同様の影響を示すのに対して, $(\mathrm{sec}-\mathrm{BuO})_{3} \mathrm{Al}$ を触媒とする場合は溶媒の誘電率が変化してもポリマーの構造は変化しなかった。これらの重 合条件によるポリマー構造の変化は, 重合系中のモノマー榩度の変化, および対イオンの錯合体生成能力によ って説明される。また, 収率の増加, および重合温度の增大とともにポリマーの分子量が増加する采では, ポ リマー間の付加反店が起こっていると考えられる。
\end{abstract}

\section{1. 緒言}

アクリルアミドのアニオン転位重合については, 触媒 にアルコキシドを用いた研究が多い。その重合機構に関 しては，次のような考えが報告されている。まず， $t-$ $\mathrm{BuONa}$ 触媒采での反応速度の研究においてて ${ }^{2)}$, 生長反 応は (1) 式の分子内プロトン転位を含む反応であること が，(2) 式の成立することから推定された。

$$
\begin{aligned}
& \mathrm{RO}-\left(-\mathrm{CH}_{2} \mathrm{CH}_{2} \mathrm{CONH}-\right)_{n}-\mathrm{CH}_{2} \mathrm{CH}_{2}-\mathrm{CONH} \\
& +\mathrm{CH}_{2}=\mathrm{CHCONH}_{2} \\
& \stackrel{k_{1}}{\longrightarrow} \mathrm{RO}-\left(-\mathrm{CH}_{2} \mathrm{CH}_{2} \mathrm{CONH}-\right)_{n+1}-\mathrm{CH}_{2} \mathrm{CH}=\stackrel{\mathrm{C}-\mathrm{NH}_{2}}{\mathrm{O}} \\
& \stackrel{\text { fast }}{\longrightarrow} \mathrm{RO}-\left(-\mathrm{CH}_{2} \mathrm{CH}_{2} \mathrm{CONH}-\right)_{n+1}-\mathrm{CH}_{2} \mathrm{CH}_{2}-\mathrm{CONH} \stackrel{\ominus}{\mathrm{C}}
\end{aligned}
$$

$$
\frac{d[\mathrm{M}]}{d t}=-k_{1}[\mathrm{M}]\left[\mathrm{M}^{*}\right]
$$

また, 谷ら ${ }^{3)}$ は開始反応には，(3) と（4) 式の両者が存

\footnotetext{
* 京都大学工学部高分子化学教室 (京都市左京区吉田泉殿町)
}

$$
\begin{aligned}
\mathrm{CH}_{2} & =\mathrm{CHCONH}_{2}+\stackrel{\ominus}{\mathrm{B}} \\
& \leftrightarrows \mathrm{CH}_{2}=\mathrm{CHCON} \stackrel{\ominus}{\mathrm{N}}+\mathrm{BH}
\end{aligned}
$$

$$
\mathrm{CH}_{2}=\mathrm{CHCONH}_{2}+\stackrel{\ominus}{\mathrm{B}} \rightleftarrows \mathrm{BCH}_{2} \stackrel{\ominus}{\mathrm{C}} \mathrm{HCONH}_{2}
$$

在し, $\stackrel{\ominus}{\mathrm{B}}$ の構造によってその起こりやすさの 異なるこ とを見出した。また，われわれ゙) は種々の金属アルコキ シドを触媒とする場合の重合を定性的に検討し, 対イオ ンの塩基性が強いほど, 極性溶媒中ほど (1) の分子内プ ロトン転位反応が促進されて, 転位重合しやすいものと 考えた。

しかし，従来の報告はすべて転位重合の割合が定量的 に求めら㞦ていないため, 詳細な議論は困難であった。

前報でアクリルアミドの転位重合においてポリマー構 造の割合を定量的に求めることが可能となったので，本 報告では種々の重合条件の変化によるポリマー構造の変 化を定量的に検討し，その機構に関する知見を得ようと した。

ここでは触媒を sec-BuONa に限定し, 触媒濃度, モ ノマー濃度, 重合溶媒, 重合温度などの重合条件を変化 
させホポリマーの構造および分子量に及ぽす影響を検討 した。また, 比較のため一部 $\mathrm{Ca}$ および $\mathrm{Al}$ アルコキシ ドを触媒に用いた。

\section{2. 実験}

\section{1 試 薬}

アクリルアミド $(\mathrm{AAm}):$ 市販品を少量のクロロホル ムを含んだベンゼンにて，3回再結晶して使用した。 mp $85^{\circ} \mathrm{C}$ (文献值 $84.5^{\circ} \mathrm{C}$ )。

ナトリウム sec-ブトキシド [sec-BuONa], およびカ ルシウム sec-ブトキシド $\left[(\sec -\mathrm{BuO})_{2} \mathrm{Ca}\right] ： \mathrm{Na}$ ，また は Ca と sec-ブタノールを $100^{\circ} \mathrm{C}$ で約 2 時間反応後, 過剩のアルコールを蒸発除去して 合成した。使用前に $180^{\circ} \mathrm{C}$ にて約 2 時間乾燥した。

アルミニウム sec-ブトキシド $\left[(\sec -\mathrm{BuO})_{3} \mathrm{Al}\right]:$ 市販 品をそのまま使用した。

トルエン，クロルベンゼン，ニトロベンゼン， ジオキ サン，ピリジン：市販特級品を常法 ${ }^{5}$ により精製使用し た。

ジメチルホルムアミド(DMF), p-シメン：市販特級 品を $\mathrm{CaH}_{2}$ にて脱水後, 2 回減圧蒸留した。

\section{2 重合操作}

a) $200 \mathrm{ml}$ の泠却管つきェルレンマイヤーに所定量 のモノマー, 溶媒およびラジカル重合禁止剤(フェニルー ß-ナフチルアミン： $0.1 \sim 0.2 \mathrm{~g} / 100 \mathrm{ml}$ ) を入れ所定の 温度に加熱後, 窒素気流中で触媒を加え, 窒素ふんい気 下で反応させた。所定時間反応後, 約 10 倍量の塩酸酸 性メタノールを添加して反応を停止した。その不溶部を 室温でロ別後, 減圧乾燥してポリマーの収量とした。さ らに必要なときには, 口液からメタノールを蒸発除去し, さらに多量のアセトンを注ぎ，その室温での不溶部を口 別乾燥してアセトン不溶部を得た。しかし，特にことわ らないかぎりポリマーはメタノール不溶部である。

b) ポリマーの分子量はポリマーの $1 \%$ ギ酸溶液の $30^{\circ} \mathrm{C}$ の粘度数 $\left(\eta_{s p} / C\right)$ で比較した。

c） ポリマー組成の定量： 前報にに述べたポリマー の IR スペクトルの $D$ 比および第一級アミドの定量か ら, 転位重合の割合 ( $T$ 比) を求めた。

\section{3. 結果および考察}

\section{1 水およびアルコールの影辢}

重合系中には，モノマーや溶媒中に除去しえない水分 と, 触媒に残存するアルコールが不純物として混入する 可能性がある。これらの不純物の影響を検討するため, 水およびアルコールを添加した実験を行なった。

Table 1 に示すように, 水の添加によってポリマーの $T$ 比, および $\eta_{s p} / C$ ともにほとんど変化は見ら礼なか った。
Table 1. Effect of water concentration.

\begin{tabular}{c|c|c|c}
\hline \hline $\begin{array}{c}\mathrm{H}_{2} \mathrm{O} \\
(\mathrm{mmol} / l)\end{array}$ & $\begin{array}{c}\text { Yield } \\
(\%)\end{array}$ & $\eta_{s p} / C$ & $T$-ratio \\
\hline 0.2 & 98 & 0.25 & 0.77 \\
15.6 & 100 & 0.24 & 0.73 \\
\hline
\end{tabular}

$[\mathrm{M}]_{0} 1.41 \mathrm{~mol} / l,[\mathrm{C}]_{0} 0.011 \mathrm{~mol} / l(\sec -\mathrm{BuONa})$, Solvent: Toluene, Temperature $100^{\circ} \mathrm{C}$, Time $2 \mathrm{hr}$

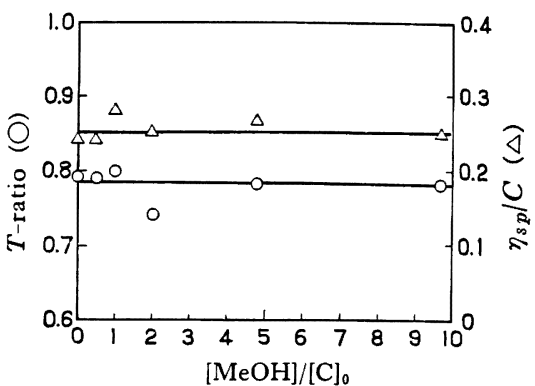

$[\mathrm{M}]_{0} 1.41 \mathrm{~mol} / l$, Catalyst : $\mathrm{sec}-\mathrm{BuONa}(0.011 \mathrm{~mol} / l)$, Solvent: Toluene, Temperature $100^{\circ} \mathrm{C}$, Time $2 \mathrm{hr}$

Fig. 1. Effect of methyl alcohol concentration on the structure of polymer.

メタノールの添加の影響を Fig. 1 に示した。メタノ ールを触媒の 10 倍量添加しても, ポリマーの $T$ 比, お よび $\eta_{s p} / C$ ともに変化は見られなかった。また,これ らの条件ではメタノールの添加にかかわらず，ほぼ定量 的にポリマーを得ることができた。メタノールの添加方 法として, 溶媒にメタノールを添加するものと, 触媒系 にメタノールを添加して熟成させたものと 2 とおり行な ったが，両者の間に差異は認められなかった。

以上の結果から，不純物として考えられる水とアルコ ールは,ポリマーの $T$ 比および $\eta_{s p} / C$ に影響を及ぼさ ないものと考えられる。

\section{2 ポリマー収率の影艟}

ポリマーの $T$ 比および $\eta_{s p} / C$ の収率による変化につ いて,トルェン中の重合結果を Fig. 2 に示した。 $T$ 比 は収率 60\% 付近から収率とともに増大した。それゆえ 以下の実験では, 重合後期の $T$ 比の一定になる範囲 (80\% 以上)で $T$ 比を求めることにした。重合条件に よっては低收率で重合が停止することがあるが，この場 合には最終収率をとった。

収率の増加に伴うポリマーの $\eta_{s p} / C$ の増加も顕著で ある。この現象から，(1) 式の連鎖生長反応以外にも， ポリマー, およびオリゴマー間の反応の存在が考えられ る。このことは, 3.3 項で確かめた。

\section{3 モノマーおよび触媒搌度の影䇾}

ポリマーの $T$ 此, および $\eta_{s p} / C$ のノマー初濃度 $\left([\mathrm{M}]_{0}\right)$ による変化について, トルェン中の重合結果を 


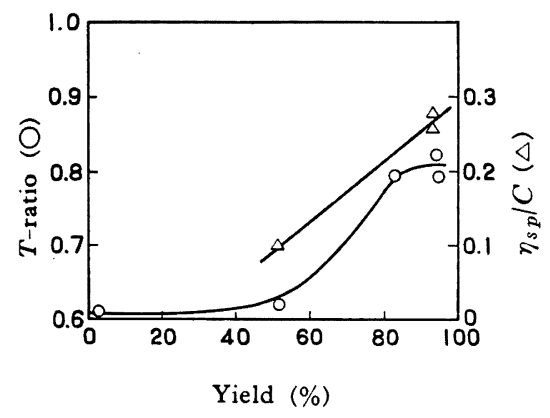

$[\mathrm{M}]_{0} 0.85 \mathrm{~mol} / l$, Catalyst : $s e c-\mathrm{BuONa}(0.011 \mathrm{~mol} / l)$, Solvent: Toluene, Temperature $100^{\circ} \mathrm{C}$

Fig. 2. Effect of polymer yield on the structure of polymer.

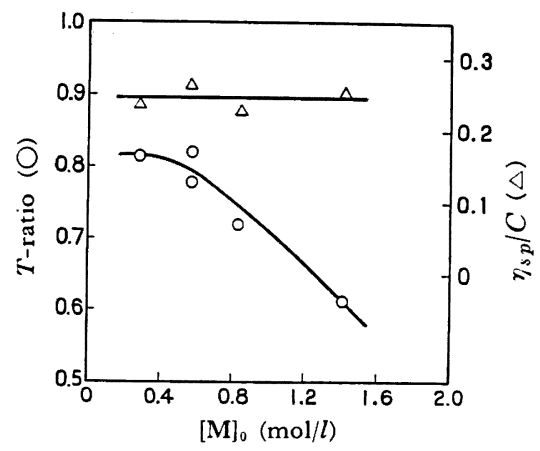

Catalyst : $s e c-\mathrm{BuONa}(0.0056 \mathrm{~mol} / l)$,

Solvent: Toluene, Temperature $100^{\circ} \mathrm{C}$, Time $2 \mathrm{hr}$

Fig. 3. Effect of monomer concentration on the structure of polymer.

Fig. 3 に示した。ここで収率はすべて $90 \%$ 以上で市 った。モノマー濃度によって $\eta_{s p} / C$ は亦まり変化しな いが，モノマー濃度を増加させると $T$ 比は急激に減少 して,ビニル重合部分の多いポリマーを得た。ここで付 加重合のみを考えると, 転位重合とビニル重合の割合は, カルバニオンにモ/マーが付加する反応 (5) と，カルバ ニオンが転位して窒素アニオンになる反応 (6) との速度 比によって決まると考えられる。そこで，重合系中のモ ノマー濃度が多ければ，(5) 式の反応が速くなってビニ

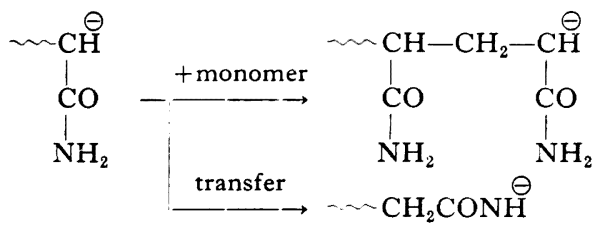

ル重合物が得られやすいことは容易に推察される。この ように考えると, モノマー濃度による $T$ 比の減少, お よび収率による $T$ 比の増加が説明される。
ポリマーの $T$ 比, および $\eta_{s p} / C$ の触媒初濃度 $\left([\mathrm{C}]_{0}\right)$ による変化について, トルェン中 $100^{\circ} \mathrm{C}$ での重合結果 を Fig. 4 に示した。これらの収率は $[C]_{0}=1 \mathrm{~m} \mathrm{~mol} / l$

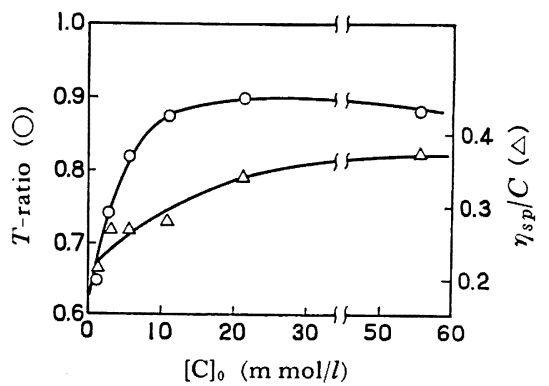

$[\mathrm{M}]_{0} 0.56 \mathrm{~mol} / l$, Catalyst : sec-BuONa,

Solvent: Toluene, Temperature $100^{\circ} \mathrm{C}$, Time $2 \mathrm{hr}$

Fig. 4. Effect of catalyst concentration on the structure of polymer.

の場合（収率 65\%) を除いてはすべて $80 \%$ 以上であっ た。触媒濃度が増加寸るにつれて $T$ 比は増加し, $[C]_{0}$ が $10 \mathrm{~m} \mathrm{~mol} / l$ 以上になると $T$ 比はほぼ一定值に達し た。これは, 触媒濃度を大に寸ることによって, 後に述 べる対イオンの作用が大きくなるためかむしれない。ま た, $\eta_{s p} / C$ も触媒濃度とともに増加する傾向にあった。 これは, 高触媒濃度でポリマー, 扔よびオリゴマー間の 反応が促進されるためであろう。

\section{4 重合温度の影響}

重合温度の影響を，無極性溶媒としてp-シメン，極 性溶媒としてニトロベンゼンを選んで検討した。無極性 溶媒として，トルェンの代わりに p-シメンを用いたの

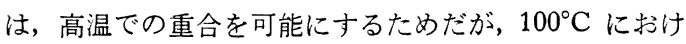
る同一の重合条件では， $p$-シメンとトルェン中で同様の $T$ 比を示した。

ポリマーの $T$ 比,および $\eta_{s p} / C$ の重合温度による変 化について, p-シメン中の重合結果を Fig. 5 に示した。

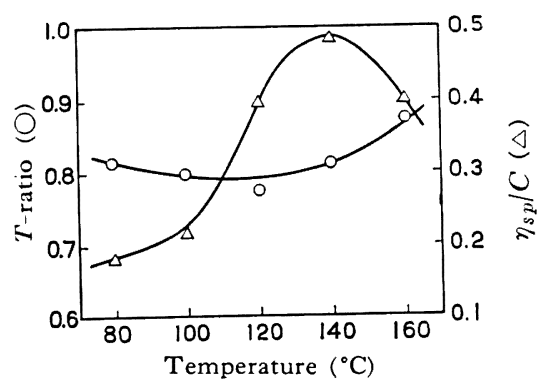

$[\mathrm{M}]_{0} 0.56 \mathrm{~mol} / l$, Catalyst : sec-BuONa $(0.011 \mathrm{~mol} / l)$, Solvent : $p$-cymene, Time $1 \mathrm{hr}$

Fig. 5. Effect of polymerization temperature on the structure of polymer. 
ここで収率はすべて $90 \%$ 以上であった。 $80 \sim 160^{\circ} \mathrm{C}$ の 範囲で, 重合温度の増加とともに $T$ 比はほとんど変化 しないが, $\eta_{s p} / C$ は特に高温の場合を除き重合温度とと もに増大した。これは, クロルベンゼンなどを溶媒とし た場合, $80^{\circ} \mathrm{C}$ から $115^{\circ} \mathrm{C}$ の温度範囲で重合温度を上げ ると, 高分子量の $\mathrm{H}_{2} \mathrm{O}$ 不溶部分が得られやすいとい5 緒方 ${ }^{6)}$ の結果と一致する。この結果の説明としては, 3.1 で述べたようにポリマー, およびオリゴマー間の反応を 考えて, 高温になるほどこの反応が促進されるものとし て説明される。この反応としては，(3) 式の開始反応あ るいはモノマー移動反応によってポリマー末端に存在す る二重結合に活性末端の攻揧する反応が考えやすい。ゆ えに, ポリマーの分子量を規定するためには，停止反応 を規定するだけではなく，ポリマーどうしの反応を規定 する因子も考虑しなければならないと考えられる。

ポリマーの $T$ 比, および $\eta_{s p} / C$ の重合温度による変 化について, ニトロベンゼン中の重合結果を Fig. 6 に 示した。ここで,メタノール不溶性のポリマーの収率は 20 40\% で, 重合温度の低いほど その収率は大きかっ た。しかし,メタノールに可溶でアセトン不溶性のオリ

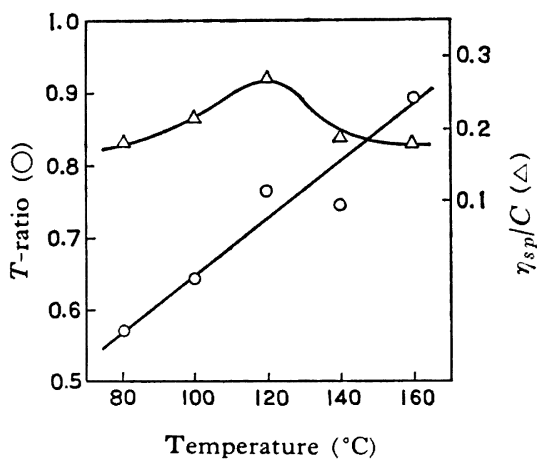

$[\mathrm{M}]_{0} 0.56 \mathrm{~mol} / l$, Catalyst : $\mathrm{sec}-\mathrm{BuONa}(0.011 \mathrm{~mol} / l)$, Solvent: Nitrobenzene, Time $1 \mathrm{hr}$

Fig. 6. Effect of polymerzation temperature on the structure of polymer.
ゴマーが得られ，モノマーの多くは低分子量のポリマー に変化していることがわかった。ニトロベンゼン中の場 合には重合温度の増加とともに $T$ 比は増加した。この 采では, ビニル重合よりも転位反応に要する活性化エネ ルギーは大きく, Fig. 6 から求めるとその差は約 $8 \mathrm{kcal} /$ $\mathrm{mol}$ であった。 $\eta_{s p} / C$ は $p$-シメン中の場合と比較して 重合温度による変化が小さかった。

\section{5 重合溶媒の影響}

極性抢よび構造の異なった溶媒を用いて重合を行なっ た結果を Table 2 に示した。溶媒の種類による $T$ 比 の変化を検討するために, 溶媒の誘電率を尺度として $100^{\circ} \mathrm{C}$ に扔ける $T$ 比の変化を見ると Fig. 7 のよ5に なった。図から明らかなように, 溶媒の誘電率による変 化から考えて, 溶媒は二つの型に分けられる。すなわち, トルェン, クロルベンゼン, ニトロベンゼンなどの芳香 族采溶媒と、ジオキサン, ピリジン, DMF などのカチ オンを溶媒和しやすい塩基性溶媒とである。

芳香族系溶媒では, 溶媒の誘電率が小さいほど転位重 合の割合は大きかった。活性末端における対カチオンの 作用, およびモノマーの極性基の対イオンに対する錯合 体生成能力は, 低誘電率溶媒で大きくなると考えられる ので，付加モノマーに対する対イオンの作用を大きくす ることによって，転位重合を促進できると考えられる。 また, 塩基性溶媒中では, 芳香族系溶媒とは逆に溶媒の 誘電率が高いほど転位重合の割合は大きかった。塩基性 溶媒では, 高誘電率溶媒で対イオンの溶媒和は大きくな るものと考えられるので, 活性末端における対イオンの 作用を極度に小さくすることによっても，転位重合が促 進される可能性があることも考えられる。この溶媒によ る二つの $T$ 比の変化は興味ある現象であるが, その内 容については今後の研究課題である。

$3.6(\mathrm{sec}-\mathrm{BuO})_{2} \mathrm{Ca}$ および $(\mathrm{sec}-\mathrm{BuO})_{3} \mathrm{Al}$ による重 合

アルコキシド触媒における 金属の影響を調べるため, $(\mathrm{sec}-\mathrm{BuO})_{2} \mathrm{Ca}$ および $(\mathrm{sec}-\mathrm{BuO})_{3} \mathrm{Al}$ を用いて二三の溶 媒中で重合を行なった。

Table 2. Effect of solvent on polymerization.

\begin{tabular}{l|c|c|c|c|c}
\hline \multicolumn{1}{c|}{ Solvent } & $\varepsilon^{\mathrm{a}}$ & {$[\mathrm{C}]_{0}(\mathrm{~mol} / l)$} & Yield $(\%)$ & $\eta_{s p} / C$ & $T$-ratio \\
\hline Toluene & $2.4\left(25^{\circ} \mathrm{C}\right)$ & 0.022 & 100 & 0.32 & 0.90 \\
Chlorobenzene & $5.6\left(25^{\circ} \mathrm{C}\right)$ & 0.033 & 98 & 0.39 & 0.82 \\
Nitrobenzene & $34.8\left(20^{\circ} \mathrm{C}\right)$ & 0.033 & 80 & 0.27 & 0.71 \\
DMF & $26.6\left(25^{\circ} \mathrm{C}\right)$ & 0.033 & 72 & 0.29 & 0.93 \\
Pyridine & $12.3\left(25^{\circ} \mathrm{C}\right)$ & 0.033 & 57 & 0.38 & 0.81 \\
Dioxane & $2.2\left(25^{\circ} \mathrm{C}\right)$ & 0.022 & 55 & 0.22 & 0.77 \\
\hline
\end{tabular}

a) Dielectric constant of solvent $[\mathrm{M}]_{0} 0.56 \mathrm{~mol} / l$, Temperature $100^{\circ} \mathrm{C}$, Catalyst : sec-BuONa, Time $2 \mathrm{hr}$ (DMF $3 \mathrm{hr}$ ) 


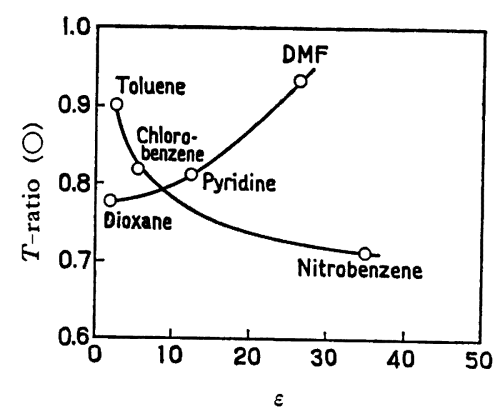

Fig. 7. The relations between dielectric contant of solvent and $T$-ratio from Table 2 .

$(\mathrm{sec}-\mathrm{BuO})_{2} \mathrm{Ca}$ を用いた場合の結果を Table 3 に示 した。いずれの溶媒中でも収率はほぼ $100 \%$ に近い值 が得られた。ポリマーの $T$ 比および $\eta_{s p} / C$ は, 他の溶 媒に比してニトロベンゼン中ではやや小さかった。この 傾向は sec-BuONa の場合と同様である。

同様に, (sec-BuO $)_{3} \mathrm{Al}$ による重合の結果を Table 4 に示した。重合速度は遅く, 12 時間反応させてもメタ， ール不溶部は 10 20\% の収率しか得られず，モノマー の多くはアセトン不溶の低分子量のポリマーに変化して いた。 $T$ 比は sec-BuONa の場合と異なり，溶媒によ ってほとんど差は認められなかった。このことは $\mathrm{Al}$ が $\mathrm{Na}$ や Ca に比して錯合体生成能力が大きいため, Lewis
塩基性の乏しい芳香族溶媒の影響を受けにくいと考えら れる。

以上の結果から, 触媒を 1 種類に限定しても, ポリマ 一収率, モノマー濃度, 触媒濃度, 重合溶媒を変えるこ とによって, ポリマー構造が変化することが明らかとな った。中でも，モノマー濃度を上げることによって現在 までに知られているよりも，かなりビニル重合の割合の 多いポリマーを得ることができた。

また，重合条件によるポリマー構造の変化を説明する ためには，モノマー濃度と対イオンの作用の二つの因子 が転位重合を支配する重要な因子だと考えられる。

付 記：本報告の一部は, 日本化学会第 17 年会 (1964 年) に 発表した。

$$
\text { 文献 }
$$

1) 中山博之, 東村敏延, 岡村誠三: 高化, 23, 433 (1966)

2) N. Ogata: Makromol. Chem., 40, 55(1960)

3) H. Tani, N. Oguni, T. Araki : Makromol. Chem., 76, 82 (1964)

4) 岡村誠三, 東村敏延, 妹尾忠雄：高化，20，364 (1963)

5) 桑田 勉：「溶剤」，(1947）丸善

6) N. Ogata : Bult. Chem. Soc. Japan, 33, 906(1960)

Table 3. Effect of solvent on polymerization by $(\sec -\mathrm{BuO})_{2} \mathrm{Ca}$.

\begin{tabular}{c|l|c|c|c|c}
\hline \hline No. & Solvent & {$[\mathrm{C}]_{0}(\mathrm{~mol} / l)$} & Yield $(\%)$ & $\eta_{s p} / C$ & $T$-ratio \\
\hline 63 & Toluene & 0.024 & 99 & 0.41 & 0.86 \\
64 & Toluene & 0.048 & 100 & 0.33 & 0.87 \\
65 & Chlorobenzene & 0.048 & 100 & 0.40 & 0.89 \\
66 & Nitrobenzene & 0.024 & 78 & 0.20 & 0.77 \\
67 & Nitrobenzene & 0.060 & 97 & 0.22 & 0.80 \\
\hline
\end{tabular}

$[\mathrm{M}]_{0} 1.41 \mathrm{~mol} / \mathrm{l}$, Temperature $100^{\circ} \mathrm{C}$, Time $5 \mathrm{hr}$

Table 4. Effect of solvent on polymerization by $(\sec -\mathrm{BuO})_{3} \mathrm{Al}$.

\begin{tabular}{c|l|c|c|c|c}
\hline \multirow{2}{*}{ No. } & \multicolumn{1}{|c|}{ Solvent } & $\begin{array}{c}{[\mathrm{C}]_{0}} \\
(\mathrm{~mol} / l)\end{array}$ & $\begin{array}{c}\text { Yield of methanol } \\
\text { insoluble part }(\%)\end{array}$ & $\begin{array}{c}\text { Yield of acetone } \\
\text { insoluble part }(\%)\end{array}$ & $\begin{array}{c}T \text {-ratio of methanol } \\
\text { insoluble part }(\%)\end{array}$ \\
\hline $\mathbf{5 2}$ & Toluene & 0.10 & 9 & 46 & 0.80 \\
$\mathbf{5 3}$ & Toluene & 0.15 & 11 & - & 0.80 \\
$\mathbf{5 4}$ & Chlorobenzene & 0.10 & 6 & - & - \\
$\mathbf{5 5}$ & Chlorobenzene & 0.15 & 12 & 67 & 0.84 \\
$\mathbf{5 6}$ & Nitrobenzene & 0.10 & 23 & - & 0.80 \\
$\mathbf{5 7}$ & Nitrobenzene & 0.15 & 19 & 78 & 0.81 \\
\hline
\end{tabular}

$[\mathrm{M}]_{0} 1.41 \mathrm{~mol} / \mathrm{l}$, Temperature $100^{\circ} \mathrm{C}$, Time $12 \mathrm{hr}$ 


\title{
The Transition Polymerization of Acrylamide by Anionic Mechanism
}

\author{
II. The Relationship between Polymer Structure \\ and Polymerization Conditions in the System \\ of Metal sec-Butoxide Catalysts
By Hiroyuki Nakayama*, Toshinobu Higashimura* and Seizo Okamura*

\begin{abstract}
The relationship between the structure of the polymer and the polymerization conditions have been studied by using the analytical method described in the previous paper. In the polymerization with sec-BuONa catalyst, a polymer with a large fraction of transition units is produced in high conversion with high catalyst and low monomer concentration. In aromatic solvents, the fraction of transition units in the polymer decreases with increasing solvent polarity. Otherwise, using basic solvents, such as, dioxane, pyridine and dimethylformamide, the amount of the transition unit in the polymer increases as the polarity of the solvent increases. Similar results are obtained when $(\mathrm{sec}-\mathrm{CuO})_{2} \mathrm{Ca}$ is used as a catalyst. However, the structure of the polymer obtained with $(\mathrm{sec}-\mathrm{BuO})_{8} \mathrm{Al}$ is independent of the polarity of a solvent. These results show that the structure of the resultant polymer is mainly controlled by the monomer concentration and by the strength of the catalyst in complex formation with an amide group. In the system for which the moleular weight of the polymer increases as the polymerization temperature is raised and as the degree of conversion is increased, it is supposed that the resultant polymer molecule adds to another polymer molecule.
\end{abstract}

* Department of Polymer Chemistry, Faculty of Engineering, Kyoto University (Kyoto) 